\title{
PENGARUH EFIKASI DIRI, MOTIVASI KERJA, LINGKUNGAN KERJA TERHADAP KEPUASAN KERJA KARYAWAN PT. SUKANDA DJAYA DENPASAR
}

\author{
Agus Santoso ${ }^{1}$ \\ I.G.A Manuati Dewi ${ }^{2}$ \\ ${ }^{1}$ Fakultas Ekonomi dan Bisnis Universitas Udayana (Unud), Bali, Indonesia \\ email:nomixjr@gmail.com
}

\begin{abstract}
ABSTRAK
Tujuan penelitian ini adalah untuk menganalisis pengaruh efikasi diri, motivasi kerja dan lingkungan kerja terhadap kepuasan kerja karyawan. Populasi penelitian ini adalah seluruh karyawan PT. Sukanda Djaya Cabang Denpasar yang berjumlah 97 orang. Teknik pengambilan sampel yang digunakan adalah sampling jenuh, dimana seluruh anggota populasi dijadikan sampel penelitian. Metode pengumpulan data dalam penelitian ini menggunakan kuesioner. Teknik analisis yang digunakan dalam penelitian ini adalah analisis regresi linier berganda. Hasil penelitian menunjukkan bahwa efikasi diri, motivasi kerja, dan lingkungan kerja berpengaruh positif dan signifikan terhadap kepuasan kerja karyawan. Hal ini memiliki makna bahwa semakin tinggi tingkat keyakinan karyawan terhadap kemampuannya, semakin tinggi motivasi kerja yang dimiliki karyawan, dan semakin baik kondisi lingkungan kerja di PT. Sukanda Djaya Cabang Denpasar, maka akan berpengaruh pada semakin meningkatnya kepuasan kerja karyawan.

Kata kunci: efikasi diri, motivasi kerja, lingkungan kerja, kepuasan kerja
\end{abstract}

\begin{abstract}
The purpose of this study was to analyze the effect of self efficacy, work motivation and work environment on employee job satisfaction. The population of this research is all employees of PT. Sukanda Djaya Denpasar Branch numbering 97 people. The sampling technique used is saturated sampling, where all members of the population are sampled. Methods of data collection in this study using questionnaires. The analytical technique used in this study is multiple linear regression analysis. The results showed that self efficacy, work motivation, and work environment have a positive and significant impact on employee work satisfaction. This has the meaning that the higher level of employee confidence in the company, the higher the employee's motivation, and the better the working environment in PT. Sukanda Djaya Denpasar Branch, it will affect the increasing employee job satisfaction Keywords: self-efficacy, job motivation, job environment, job satisfaction
\end{abstract}




\section{PENDAHULUAN}

Setiap organisasi dituntut untuk dapat mengoptimalkan unsur sumber daya manusia yang dimiliki karena unsur ini merupakan salah satu faktor penentu keberhasilan sebuah organisasi untuk mencapai tujuannya. Menurut (Waspodo \& Minadaniati, 2012), sumber daya manusia memiliki peranan yang sangat penting dalam organisasi karena tanpa didukung sumber daya manusia yang baik, organisasi akan menghadapi masalah dalam pencapaian tujuannya. Penting bagi organisasi untuk memperhatikan kesejahteraan karyawan sebagai sumber daya utama dalam menggerakkan organisasi. Demi tercapainya tujuan organisasi, organisasi perlu fokus dalam hal kesejahteraan karyawan yang nantinya dapat berpengaruh pada kepuasan kerja dan loyalitas kerja, sehingga karyawan dapat memberikan kontribusi yang maksimal pada organisasi (Soeghandi et al., 2013).

Kepuasan kerja merupakan penilaian, perasaan atau sikap seseorang terhadap pekerjaannya. Variabel ini berhubungan dengan lingkungan kerja, jenis pekerjaan, kompensasi, hubungan antar teman kerja, hubungan sosial di tempat kerja, dan sebagainya. Dapat dikatakan bahwa kepuasaan kerja adalah dipenuhinya beberapa keinginan dan kebutuhannya melalui kegiatan kerja atau bekerja (Koesmono, 2005). Kondisi ini menyebabkan organisasi perlu memperhatikan penilaian tentang kepuasan kerja karyawan dengan cara mengkaji ulang aspek-aspek yang mempengaruhi tingkat kepuasan kerja diantaranya adalah efikasi diri, motivasi kerja, dan lingkungan kerja.

(Betz, 2004) menyatakan bahwa efikasi diri merupakan keyakinan individu bahwa ia dapat berhasil menjalankan perilaku yang dibutuhkan oleh situasi tertentu. Peran motvasi dan efikasi diri sangat diperlukan agar para karyawan mampu bekerja dengam baik dan memiliki kepuasan kerja yang tinggi. (Mishra et al., 2016) menyatakan bahwa peningkatan efikasi diri kemungkinan akan mendorong tumbuhnya kepuasan kerja. Hasil penelitian tersebut sejalan dengan temuan (Pahi et al., 2017) dan (Karabiyik \& Korumaz, 2014) yang menyatakan bahwa efikasi diri berpengaruh postif terhadap kepuasan kerja.

(Ahmed, 2014) menyatakan bahwa motivasi dapat diuraikan sebagai arah atau ketekunan individu dalam upaya mencapai tujuannya. (Horwitz et al., 2003) memperkirakan bahwa karyawan mendapatkan motivasi tinggi melalui lingkungan kerja yang menantang dan dukungan dari manajemen puncak. (Waeesor et al., 2016) menyatakan bahwa motivasi kerja telah menjadi salah satu indikator penting bagi karyawan dalam mengevaluasi apakah seseorang puas dengan pekerjaan mereka. Hal tersebut dapat meningkatkan kepuasan kerja bagi karyawan agar tetap menjaga kinerja dan kualitas karyawan yang mereka miliki. Pengaruh positif motivasi kerja terhadap kepuasan kerja ini didukung dengan hasil penelitian dari (Chatzopoulou et al., 2015) dan (Arasli et al., 2014).

Organisasi harus memperhatikan lingkungan kerja karyawan, karena lingkungan kerja merupakan tempat aktivitas suatu pekerjaan dilakukan serta merupakan salah satu faktor yang dapat mempengaruhi kepuasan kerja karyawan. (Gardjito et al., 2011) menyatakan bahwa lingkungan kerja adalah kondisi atau keadaan yang cukup besar mempengaruhi karyawan dalam melakukan pekerjaan atau terhadap jalannya operasi organisasi. (Jain \& Kaur, 2014) menyatakan terdapat hubungan yang positif antara lingkungan kerja dan kepuasan kerja. 
Penelitian terdahulu telah menunjukkan bahwa lingkungan kerja berpengaruh secara positif dan signifikan terhadap kepuasan kerja. Menurut (Robbins \& Judge, 2015), mayoritas karyawan lebih menyukai lingkungan kerja fisik yang bersih, nyaman, dan didukung dengan peralatan modern. Lingkungan kerja fisik tersebut memiliki peran penting untuk menciptakan kepuasan kerja karyawan.

Penelitian ini dilakukan di PT. Sukanda Djaya Cabang Denpasar yaitu salah satu perusahaan berskala besar di Indonesia. Pada perusahaan berskala besar, kegiatan operasional dan deskripsi jabatan setiap karyawan yang ada begitu kompleks, sehingga peran kepuasan kerja karyawan menjadi sangat penting, agar tujuan perusahaan akan tercapai. Sebagai salah satu perusahaan yang cukup terkenal di Indonesia, PT. Sukanda Djaya yang bergerak dalam bidang industri makanan dan minuman selalu dituntut untuk memberikan hasil terbaik bagi konsumen. Untuk itu, perusahaan ini harus didukung oleh seluruh karyawan yang mampu bekerja sama dengan baik dan memerlukan tingkat produktivitas kerja yang tinggi sebagai salah satu upaya untuk memasuki tingkat persaingan yang ada saat ini. Elemen perusahaan yang memegang peran paling penting di dalam meningkatkan kinerja dan produktivitas perusahaan adalah sumber daya manusianya. Sumber daya manusia yang memiliki motivasi yang tinggi akan meningkatkan kinerja. Apabila karyawan memiliki kinerja yang tinggi dan mampu bekerja dengan maksimal tentunya akan memberikan kontribusi positif bagi perusahaan dalam memberikan pelayanan prima bagi konsumen.

Berdasarkan hasil wawancara di lapangan diduga ada masalah yang terjadi terkait kepuasan kerja karyawan di PT. Sukanda Djaya Cabang Denpasar, seperti yang ditunjukkan dalam Tabel 1.

Tabel 1.

Hasil Wawancara Awal tentang Kepuasan Kerja Karyawan PT. Sukanda Djaya Cabang Denpasar

\begin{tabular}{lllllllc}
\hline No & \multicolumn{1}{c}{ Keterangan } & STS & TS & N & S & SS & $\begin{array}{c}\text { Total } \\
\text { (Orang) }\end{array}$ \\
\hline 1 & Saya puas dengan pekerjaan saya & 1 & 7 & 1 & 1 & 0 & 10 \\
2 & Saya puas dengan rekan kerja saya & 3 & 5 & 0 & 1 & 1 & 10 \\
3 & Saya puas dengan pimpinan saya & 2 & 5 & 0 & 2 & 1 & 10 \\
4 & Saya puas dengan bayaran yang saya terima & 3 & 6 & 0 & 1 & 0 & 10 \\
5 & Saya puas dengan kesempatan promosi jabatan & 5 & 3 & 0 & 2 & 0 & 10 \\
\hline \multicolumn{2}{l}{ Sumber: Hasil wawancara, 2017 } & & & & & &
\end{tabular}

Tabel 1. yang menunjukkan bahwa ada permasalahan pada kepuasan kerja karyawan di PT. Sukanda Djaya Cabang Denpasar yang diperoleh berdasarkan hasil wawancara awal terhadap sepuluh orang karyawan dengan berpedoman pada indikator kepuasan kerja. Pertama, karyawan merasa beban kerja yang diberikan serta tanggung jawab terhadap pekerjaan pada bidang yang sama kurang merata sehingga karyawan cenderung melaksanakan tugas yang lebih banyak dibandingkan karyawan lainnya yang berakibat pada ketidakpuasan karyawan terhadap pekerjaan yang diberikan. Kedua, karyawan merasa gaji yang didapat masih kurang cukup sehingga karyawan yang saya wawancarai mencari penghasilan tambahan diluar jam kerja, selain itu kadang-kadang mengalami 
keterlambatan dalam penerimaan gaji dan pernah ada masalah di bidang upah yang tidak diharapkan oleh para karyawan, sehingga karyawan melakukan tuntutan dengan melakukan mogok kerja agar upah yang diberikan bertambah. Ketiga, terbatasnya kesempatan mendapatkan promosi jabatan. Keempat, masih terjadi kurang komunikasi antar rekan kerja sehingga menghambat pekerjaan yang menyebabkan pekerjaan tidak selesai tepat waktu. Dari Tabel 1 dapat dilihat bahwa lebih banyak jawaban karyawan tersebut pada poin sangat tidak setuju dan tidak setuju. Hal ini menunjukkan adanya indikasi ketidakpuasan karyawan dalam pekerjaannya.

Berdasarkan latar belakang di atas, penelitian ini bertujuan untuk menguji mengenai pengaruh efikasi diri terhadap kepuasan kerja karyawan, motivasi kerja terhadap kepuasan kerja karyawan, dan lingkungan kerja terhadap kepuasan kerja karyawan dengan subjek penelitian ini adalah karyawan PT. Sukanda Djaya Cabang Denpasar.

Pada penelitian (Lau, 2012) yang dilakukan pada Universitas di Amerika Serikat dengan menggunakan 224 mahasiswa menunjukkan bahwa efikasi diri berhubungan positif dengan kepuasan kerja. Semakin tinggi efikasi diri seseorang, semakin tinggi pula kepuasan kerjanya. Hal ini membuktikan bahwa efikasi diri yang dimiliki oleh seorang karyawan memberikan dorongan terhadap kepuasan kerja, karena mereka menganggap bahwa pada dasarnya setiap orang pasti memiliki efikasi diri. (Lodjo, 2013), dalam penelitiannya terhadap 127 karyawan PT. PLN Suluttenggo mengatakan bahwa keyakinan diri sangatlah penting. Semakin mampu dan yakin seseorang dalam mengerjakan tugasnya akan semakin tinggi kepuasan kerja karyawan tersebut.

$\mathrm{H}_{1}$ : Efikasi diri berpengaruh positif terhadap kepuasan kerja.

(Kartika \& Kaihatu, 2010) dalam penelitiannya terhadap 72 karyawan Pakuwon Food Festival menyatakan bahwa motivasi kerja berpengaruh secara signifikan terhadap kepuasan kerja karyawan. Selain penelitian yang dilakukan oleh (Brahmasari \& Suprayetno, 2008) dalam penelitiannya terhadap 1.737 orang karyawan di PT. Pei Hai International Wiratama Indonesia di Surabaya dan Jombang menyatakan bahwa motivasi kerja berpengaruh positif pada kepuasan kerja karyawan. Penelitian lainnya dilakukan oleh (Djamaludin, 2009) terhadap 200 orang pegawai negeri sipil yang ada di Kota Maba menyatakan bahwa motivasi kerja berpengaruh positif pada kepuasan kerja.

$\mathrm{H}_{2}$ : Motivasi kerja berpengaruh positif terhadap kepuasan kerja.

(Medina et al., 2013) dalam penelitiannya yang bertujuan menganalisis dampak stres dan lingkungan kerja pada pengusaha perempuan terhadap pengambilan keputusan dan kepuasan kerja di Meksiko menemukan hubungan yang positif antara lingkungan kerja dan kepuasan kerja. (Bahri et al., 2013) dalam penelitiannya yang bertujuan mengetahui hubungan variabel lingkungan kerja termasuk keadilan organisasional, konflik interpersonal dan kendala organisasi terhadap kepuasan kerja dan perilaku kerja kontraproduktif pada karyawan di Universitas Mazandaran Barat menemukan hubungan yang signifikan antara lingkungan kerja dan kepuasan kerja. (baraba, 2014) dalam penelitiannya menemukan hasil bahwa lingkungan kerja berpengaruh positif dan signifikan terhadap kepuasan kerja. (Kurniasari \& Halim, 2013) dalam 
penelitiannya pada Dinas Pasar Kabupaten menemukan hasil lingkungan kerja berpengaruh positif terhadap kepuasan kerja karyawan.

$\mathrm{H}_{3}$ : Lingkungan Kerja berpengaruh positif terhadap Kepuasan Kerja

Berdasarkan penelusuran kajian pustaka dan hasil hasil penelitian sebelumnya maka model konseptual penelitian ini dapat dilihat pada gambar 1 sebagai berikut.

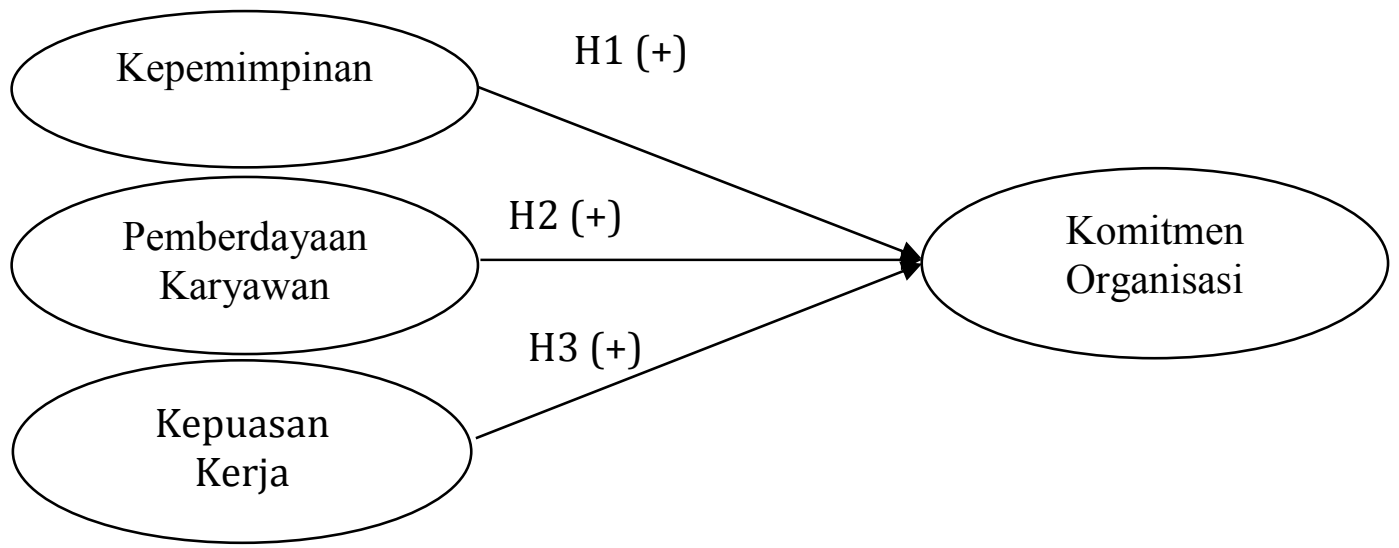

Gambar 1 Model Konseptual

Sumber : data diolah, 2018

\section{METODE PENELITIAN}

Penelitian ini digolongkan pada penelitian asosiatif (hubungan), dikatakan demikian karena penelitian ini bertujuan untuk menguji pengaruh efikasi diri, motivasi kerja, dan lingkungan kerja terhadap kepuasan kerja karyawan PT. Sukanda Djaya Cabang Denpasar. Penelitian ini dilakukan di PT. Sukanda Djaya Cabang Denpasar yang terletak di jalan By Pass Ngurah Rai. Objek penelitian, yaitu kepemimpinan, pemberdayaan karyawan, kepuasan kerja dan komitmen organisasi. Subjek penelitian yang digunakan dalam penelitian kali ini adalah karyawan PT. Sukanda Djaya Cabang Denpasar.Objek penelitian yang digunakan pada penelitian ini adalah efikasi diri, motivasi kerja, lingkungan kerja dan kepuasan kerja karyawan di PT. Sukanda Djaya Cabang Denpasar

Penelitian ini menggunakan dua jenis variabel yaitu variabel bebas, dan variabel terikat, yang secara rinci dirangkum dalam Tabel 2.

Populasi dalam penelitian ini adalah seluruh karyawan PT. Sukanda Djaya Cabang Denpasar yang berjumlah 97 orang. Teknik pengambilan sampel dalam penelitian ini adalah sampling jenuh, dimana seluruh anggota populasi dijadikan sampel penelitian. Metode pengumpulan data dalam penelitian ini menggunakan tiga metode penelitian dalam mengumpulkan data, yaitu, metode wawancara dan kuesioner. Jenis data yang digunakan dalam penelitian ini adalah data kualitatif dan data kuantitatif. Data kualitatif dalam penelitian ini berupa pendapat dari responden. Data kuantitatif dalam penelitian ini adalah data karyawan pada PT. Sukanda Djaya Cabang Denpasar. Seluruh jenis data diperoleh dari sumber primer maupun sekunder. 
Tabel 2.

Rangkuman Variabel dan Indikator Penelitian

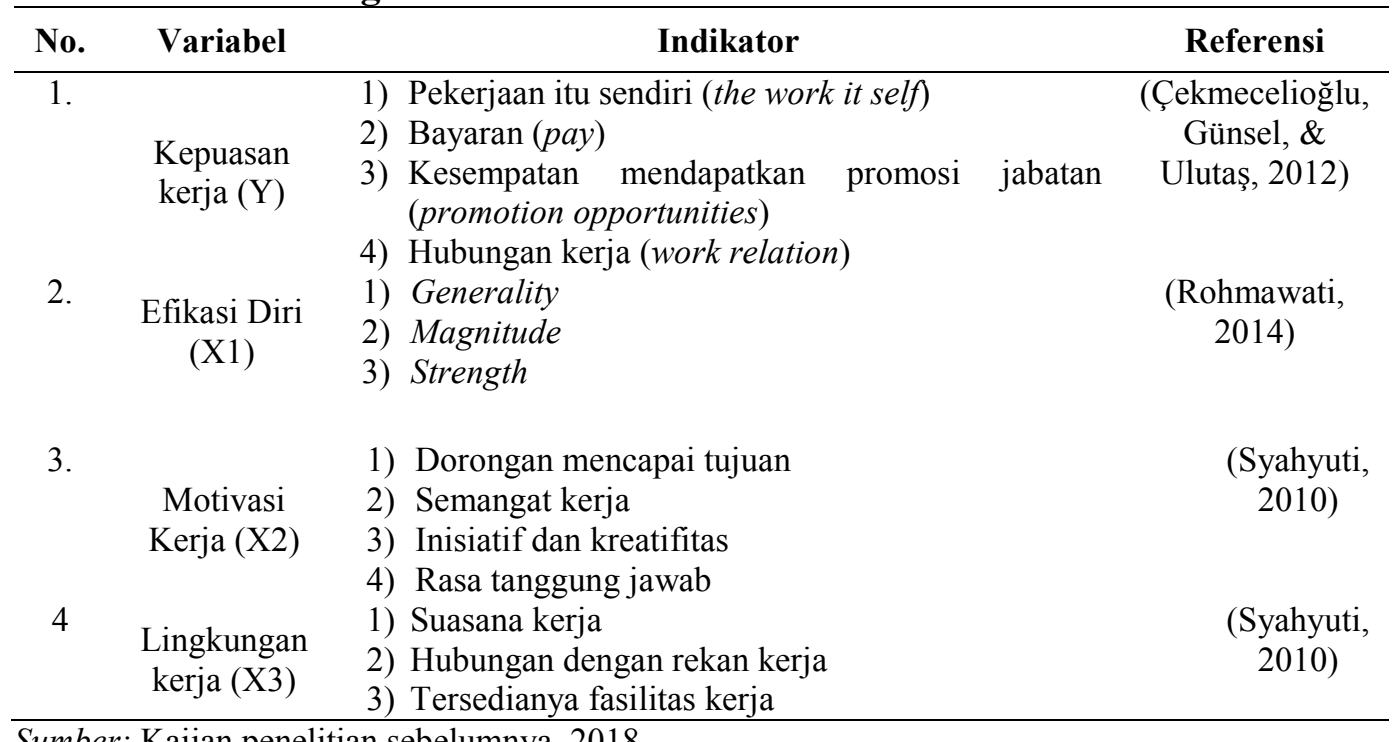

Sumber: Kajian penelitian sebelumnya, 2018

Data dalam penelitian ini dikumpulkan melalui instrumen penelitian berupa kuesioner. Penilaian untuk variabel efikasi diri, motivasi kerja, lingkungan kerja dan kepuasan kerja menggunakan satu skala yaitu Skala Likert dengan skala 1-5. Pada penelitian ini kesungguhan responden dalam menjawab pernyataan merupakan hal yang paling penting dikarenakan keabsahan (validitas) suatu hasil penelitian sangat tergantung oleh alat pengukur instrumen yang digunakan dan data yang diperoleh. Berdasarkan pertimbangan tersebut, dalam penelitian ini teknik analisis data diawali dengan pengujian instrumen yaitu dengan menguji validitas dan reliabilitas instrumen sehingga dapat diketahui apakah jawaban responden tersebut telah dijawab dengan benar atau tidak.

Data yang sudah dinyatakan layak selanjutnya dianalisis menggunakan analisis statistik deskriptif, dan analisis regresi linier berganda. Rumus model regresi linier berganda yang digunakan yaitu sebagai berikut:

$\mathrm{Y}=\alpha+\beta_{1} \mathrm{X}_{1}+\beta_{2} \mathrm{X}_{2}+\beta_{3} \mathrm{X}_{3}+\mathrm{e}$

Keterangan :

$\mathrm{Y} \quad=$ Kepuasan Kerja

$\alpha \quad=$ Konstanta

$\beta_{1} \cdot \beta_{2} \cdot \beta_{3}=$ Koefisien regresi variabel $X_{1}, X_{2}, X_{3}$

$\mathrm{X}_{1}=$ Efikasi Diri

$\mathrm{X}_{2} \quad=$ Motivasi Kerja

$\mathrm{X}_{2} \quad=$ Lingkungan Kerja

Penggunaan analisis ini karena mampu menginterpretasikan dan menjelaskan hubungan linier antara stres kerja, kepuasan kerja dan komitmen organisasi karyawan.

\section{HASIL DAN PEMBAHASAN}


Data penelitian diperoleh dari hasil kuesioner yang telah disebarkan kepada responden penelitian sejumlah 97 orang karyawan yang bekerja di PT. Sukanda Djaya Kantor Cabang Denpasar. Karakteristik responden meliputi usia, jenis kelamin, dan tingkat pendidikan responden yang dapat dilihat pada Tabel 3.

Tabel 3.

Karakteristik Karyawan PT. Sukanda Djaya Kantor Cabang Denpasar

\begin{tabular}{|c|c|c|c|c|}
\hline No & Karakteristik & Klasifikasi & $\begin{array}{c}\text { Jumlah } \\
\text { Responden } \\
\text { (orang) }\end{array}$ & $\begin{array}{c}\text { Presentase } \\
\text { Responden } \\
(\%)\end{array}$ \\
\hline \multirow{3}{*}{1} & \multirow{3}{*}{ Usia } & 18 - 28 Tahun & 44 & 45,36 \\
\hline & & 29-38 Tahun & 37 & 38,14 \\
\hline & & $>39$ Tahun & 16 & 16,49 \\
\hline \multicolumn{3}{|c|}{ Jumlah } & 97 & 100 \\
\hline \multirow{2}{*}{2} & \multirow{2}{*}{ Jenis Kelamin } & Laki-laki & 61 & 62,89 \\
\hline & & Perempuan & 36 & 37,11 \\
\hline \multirow{5}{*}{3} & \multicolumn{2}{|c|}{ Jumlah } & 97 & 100 \\
\hline & \multirow{4}{*}{$\begin{array}{c}\text { Pendidikan } \\
\text { Terakhir }\end{array}$} & SLTA & 53 & 54,64 \\
\hline & & Diploma & 12 & 12,37 \\
\hline & & Sarjana & 32 & 32,99 \\
\hline & & & 97 & 100 \\
\hline
\end{tabular}

Sumber: Data primer diolah, 2018

Tabel 3. menunjukkan bahwa responden dalam penelitian ini yaitu karyawan di PT. Sukanda Djaya Kantor Cabang Denpasar dominan berjenis kelamin laki-laki dengan persentase 62,89 persen atau 61 orang. Hal ini menunjukkan bahwa PT. Sukanda Djaya Kantor Cabang Denpasar lebih banyak membutuhkan tenaga laki-laki dibandingkan dengan perempuan. Apabila dilihat dari segi usia, responden sebagian besar berusia 18-28 tahun dengan jumlah sebanyak 44 orang dengan persentase sebesar 45,36 persen. Faktor usia seorang karyawan yang produktif dapat menunjang kegiatan organisasi dalam menghasilkan organisasi yang berkualitas, karena dengan umur produktif yang dimiliki akan berkorelasi di dalam pencapaian tujuan organisasi tersebut.

Tabel 3. juga menunjukkan bahwa mayoritas karyawan di PT. Sukanda Djaya Kantor Cabang Denpasar adalah kelompok responden dengan tingkat pendidikan SMA yaitu dengan jumlah sebanyak 53 orang atau 54,64 persen. Informasi ini memberikan gambaran bahwa lulusan SMA dianggap sudah mampu serta memadai untuk menjadi karyawan PT. Sukanda Djaya Kantor Cabang Denpasar, khususnya pada bagian distribusi, namun pada bagian administrasi dan sales/marketing yang lebih dominan adalah lulusan Sarjana.

Hasil uji pada Tabel 4. menunjukkan bahwa seluruh instrumen penelitian yang digunakan untuk mengukur variabel efikasi diri, motivasi kerja, lingkungan kerja, dan kepuasan kerja memiliki nilai koefisien korelasi dengan skor total seluruh item pernyataan lebih besar dari 0,30 dan memiliki koefisien Cronbach's Alpha lebih dari 0,60. Hal ini menunjukkan bahwa seluruh butir pernyataan dalam instrument penelitian tersebut valid dan reliabel, sehingga layak digunakan untuk penelitiaan. 
Tabel 4.

Rekapitulasi Hasil Uji Validitas dan Reliabilitas

\begin{tabular}{|c|c|c|c|c|c|}
\hline Variabel & Indikator & $\begin{array}{c}\text { Koefisien } \\
\text { Korelasi } \\
\end{array}$ & $\begin{array}{l}\text { Sig. (2- } \\
\text { tailed) }\end{array}$ & $\begin{array}{l}\text { Cronbach's } \\
\text { Alpha }\end{array}$ & Keterangan \\
\hline \multirow{9}{*}{$\begin{array}{l}\text { Kepuasan kerja } \\
\text { (Y) }\end{array}$} & $\mathrm{Y}_{1}$ & 0,781 & 0,000 & \multirow{2}{*}{0,778} & \multirow{2}{*}{$\begin{array}{l}\text { Valid dan } \\
\text { Reliabel }\end{array}$} \\
\hline & $\mathrm{Y}_{2}$ & 0,575 & 0,000 & & \\
\hline & $\mathrm{Y}_{3}$ & 0,811 & 0,000 & \multirow{3}{*}{0,778} & \multirow{3}{*}{$\begin{array}{l}\text { Valid dan } \\
\text { Reliabel }\end{array}$} \\
\hline & $\mathrm{Y}_{4}$ & 0,719 & 0,000 & & \\
\hline & $\mathrm{Y}_{5}$ & 0,612 & 0,000 & & \\
\hline & $\mathrm{X}_{1.1}$ & 0,488 & 0,006 & \multirow{9}{*}{0,765} & \multirow{12}{*}{$\begin{array}{l}\text { Valid dan } \\
\text { Reliabel }\end{array}$} \\
\hline & $\mathrm{X}_{1.2}$ & 0,694 & 0,000 & & \\
\hline & $\mathrm{X}_{1.3}$ & 0,610 & 0,000 & & \\
\hline & $\mathrm{X}_{1.4}$ & 0,680 & 0,000 & & \\
\hline \multirow{8}{*}{$\begin{array}{l}\text { Efikasi Diri } \\
\quad\left(\mathrm{X}_{1}\right)\end{array}$} & $\mathrm{X}_{1.5}$ & 0,801 & 0,000 & & \\
\hline & $\mathrm{X}_{1.6}$ & 0,622 & 0,000 & & \\
\hline & $\mathrm{X}_{1.7}$ & 0,633 & 0,000 & & \\
\hline & $\mathrm{X}_{1.8}$ & 0,778 & 0,000 & & \\
\hline & $\mathrm{X}_{1.9}$ & 0,757 & 0,000 & & \\
\hline & $\mathrm{X}_{1.10}$ & 0,770 & 0,000 & \multirow{7}{*}{0,772} & \\
\hline & $\mathrm{X}_{2.1}$ & 0,754 & 0,000 & & \\
\hline & $\mathrm{X}_{2.2}$ & 0,662 & 0,000 & & \\
\hline \multirow{5}{*}{$\begin{array}{l}\text { Motivasi Kerja } \\
\qquad\left(\mathrm{X}_{2}\right)\end{array}$} & $\mathrm{X}_{2.3}$ & 0,768 & 0,000 & & \multirow{6}{*}{$\begin{array}{l}\text { Valid dan } \\
\text { Reliabel }\end{array}$} \\
\hline & $\mathrm{X}_{2.4}$ & 0,653 & 0,000 & & \\
\hline & $\mathrm{X}_{2.5}$ & 0,853 & 0,000 & & \\
\hline & $\mathrm{X}_{2.6}$ & 0,448 & 0,013 & & \\
\hline & $X_{3.1}$ & 0,746 & 0,000 & \multirow{6}{*}{0,754} & \\
\hline \multirow{5}{*}{$\begin{array}{c}\text { Lingkungan } \\
\text { Kerja } \\
\left(\mathrm{X}_{3}\right)\end{array}$} & $X_{3.2}$ & 0,694 & 0,000 & & \\
\hline & $X_{3.3}$ & 0,562 & 0,001 & & \multirow{4}{*}{$\begin{array}{l}\text { Valid dan } \\
\text { Reliabel }\end{array}$} \\
\hline & $\mathrm{X}_{3.4}$ & 0,636 & 0,000 & & \\
\hline & $\mathrm{X}_{3.5}$ & 0,664 & 0,000 & & \\
\hline & $X_{3.6}$ & 0,677 & 0,000 & & \\
\hline
\end{tabular}

Sumber : Hasil Olahan Data, 2018

Pengumpulan data melalui kuesioner terdiri atas pernyataan responden berdasarkan masing-masing variabel, yaitu: variabel efikasi diri, motivasi kerja, lingkungan kerja, dan kepuasan kerja. Skor pada penelitian ini memiliki nilai tertinggi maksimal 5 dan terendah minimal 1.

Secara rinci hasil penelitian mengenai jawaban responden terhadap variabel efikasi diri, motivasi kerja, lingkungan kerja, dan kepuasan kerja dapat dilihat pada Tabel 6, Tabel 7, Tabel 8. dan Tabel 9. berikut.

Hasil analisis deksriptif sebagaimana disajikan pada Tabel 6. menunjukkan bahwa variabel kepuasan kerja secara keseluruhan memperoleh nilai rata-rata sebesar 2,99, yang berarti bahwa sebagian besar karyawan PT. Sukanda Djaya Cabang Denpasar memiliki kepuasan kerja yang cukup rendah. Dari 5 pernyataan yang digunakan untuk mengukur kepuasan kerja, maka terdapat 3 pernyataan yang nilainya berada di atas nilai rata-rata $(2,99)$. Dari ketiga pernyataan tersebut, yang memiliki nilai paling tinggi adalah pernyataan, "Saya puas dengan rekan kerja saya ". Hal tersebut disebabkan karena secara keseluruhan karyawan PT. 
Sukanda Djaya Cabang Denpasar memiliki hubungan yang baik antar karyawan dan saling membantu rekan kerja yang mengalami kesulitan dalam pekerjaan, sehingga kepuasan kerja karyawan pada PT. Sukanda Djaya Cabang Denpasar mampu terbentuk dengan baik. Skor rata-rata terendah pada variabel kepuasan kerja terdapat pada pernyataan "Saya puas dengan kesempatan untuk promosi jabatan", dengan nilai rata-rata sebesar 2,88. Hal tersebut menunjukkan bahwa masih banyak karyawan yang merasa tidak mendapatkan kesempatan untuk promosi jabatan di PT. Sukanda Djaya Cabang Denpasar.

Tabel 5.

Kriteria Pengukuran Deskripsi Variabel Penelitian

\begin{tabular}{ccccc}
\hline Nilai Skor & Efikasi Diri & Motivasi Kerja & Lingkungan Kerja & $\begin{array}{c}\text { Kepuasan } \\
\text { kerja }\end{array}$ \\
\hline $1,00-1,80$ & Sangat Rendah & Sangat Rendah & Sangat Tidak Baik & Sangat Rendah \\
$1,81-2,60$ & Rendah & Rendah & Tidak Baik & Rendah \\
$2,61-3,40$ & Cukup Rendah & Cukup Rendah & Kurang Baik & Cukup Rendah \\
$3,41-4,20$ & Tinggi & Tinggi & Baik & Tinggi \\
$4,21-5,00$ & Sangat Tinggi & Sangat Tinggi & Sangat Baik & Sangat Tinggi \\
\hline
\end{tabular}

Sumber : Hasil Olahan Data, 2018

Tabel 6.

Deskripsi Penilaian Responden Terhadap Variabel Kepuasan kerja

\begin{tabular}{|c|c|c|c|c|c|c|c|}
\hline \multirow[t]{2}{*}{ Indikator } & \multicolumn{5}{|c|}{$\begin{array}{l}\text { Frekuensi Jawaban } \\
\text { Responden }\end{array}$} & \multirow[t]{2}{*}{$\begin{array}{l}\text { Rata - } \\
\text { Rata }\end{array}$} & \multirow[t]{2}{*}{ Keterangan } \\
\hline & 1 & 2 & 3 & 4 & 5 & & \\
\hline Saya puas dengan pekerjaan saya $\left(\mathrm{Y}_{1}\right)$ & 3 & 20 & 45 & 28 & 1 & 3,04 & Cukup Rendah \\
\hline Saya puas dengan rekan kerja saya $\left(\mathrm{Y}_{2}\right)$ & 3 & 20 & 41 & 31 & 2 & 3,09 & Cukup Rendah \\
\hline Saya puas dengan pimpinan saya $)\left(\mathrm{Y}_{3}\right)$ & 3 & 21 & 45 & 26 & 2 & 3,03 & Cukup Rendah \\
\hline $\begin{array}{l}\text { Saya puas dengan bayaran yang saya } \\
\text { terima }\left(\mathrm{Y}_{4}\right)\end{array}$ & 4 & 22 & 50 & 20 & 1 & 2,92 & Cukup Rendah \\
\hline $\begin{array}{l}\text { Saya puas dengan kesempatan untuk } \\
\text { promosi jabatan }\left(\mathrm{Y}_{5}\right)\end{array}$ & 5 & 23 & 49 & 19 & 1 & 2,88 & Cukup Rendah \\
\hline \multicolumn{6}{|c|}{ Rata-rata Skor Variabel Kepuasan Kerja } & 2,99 & $\begin{array}{l}\text { Cukup } \\
\text { Rendah }\end{array}$ \\
\hline
\end{tabular}

Sumber: Data primer diolah, 2018

Hasil analisis deksriptif sebagaimana disajikan pada Tabel 7. menunjukkan bahwa variabel efikasi diri secara keseluruhan memperoleh nilai rata-rata sebesar 3,98 yang berarti bahwa sebagian besar karyawan PT. Sukanda Djaya Cabang Denpasar sudah memiliki efikasi diri yang tinggi serta memiliki keyakinan untuk mengorganisir tindakan yang dibutuhkan untuk menghadapi permasalahan yang akan datang. Dari 10 pernyataan yang digunakan untuk mengukur efikasi diri karyawan karyawan PT. Sukanda Djaya Cabang Denpasar, maka terdapat 5 pernyataan yang nilainya berada di atas nilai rata-rata $(3,98)$ variabel efikasi diri. 
Tabel 7.

Deskripsi Penilaian Responden Terhadap Variabel Efikasi Diri

\begin{tabular}{|c|c|c|c|c|c|c|c|}
\hline \multirow[t]{2}{*}{ Pernyataan } & \multicolumn{5}{|c|}{$\begin{array}{l}\text { Frekuensi Jawaban } \\
\text { Responden }\end{array}$} & \multirow[t]{2}{*}{$\begin{array}{l}\text { Rata - } \\
\text { Rata }\end{array}$} & \multirow[t]{2}{*}{ Keterangan } \\
\hline & 1 & 2 & 3 & 4 & 5 & & \\
\hline $\begin{array}{l}\text { Saya selalu bisa mengatasi masalah sulit jika } \\
\text { saya berusaha cukup keras }\left(\mathrm{X}_{1.1}\right)\end{array}$ & 0 & 1 & 16 & 53 & 27 & 4,09 & Tinggi \\
\hline $\begin{array}{l}\text { Jika seseorang menentang saya, saya bisa } \\
\text { menemukan cara dan sarana untuk } \\
\text { mendapatkan apa yang saya inginkan }\left(\mathrm{X}_{1.2}\right)\end{array}$ & 0 & 5 & 22 & 38 & 32 & 4,00 & Tinggi \\
\hline $\begin{array}{l}\text { Saya yakin bahwa saya mencapai tujuan saya } \\
\left(\mathrm{X}_{1.3}\right)\end{array}$ & 0 & 3 & 24 & 44 & 26 & 3,96 & Tinggi \\
\hline $\begin{array}{l}\text { Saya yakin bahwa saya bisa menangani } \\
\text { kejadian tak terduga secara efisien }\left(\mathrm{X}_{1.4}\right)\end{array}$ & 1 & 5 & 20 & 43 & 28 & 3,95 & Tinggi \\
\hline $\begin{array}{l}\text { Berkat akal saya, saya bisa menangani situasi } \\
\text { yang tak terduga }\left(\mathrm{X}_{1.5}\right)\end{array}$ & 0 & 4 & 24 & 35 & 34 & 4,02 & Tinggi \\
\hline $\begin{array}{l}\text { Saya dapat memecahkan sebagian besar } \\
\text { masalah jika saya menginvestasikan usaha } \\
\text { yang diperlukan }\left(\mathrm{X}_{1.6}\right)\end{array}$ & 0 & 7 & 20 & 46 & 24 & 3,90 & Tinggi \\
\hline $\begin{array}{l}\text { Saya bisa tetap tenang saat menghadapi } \\
\text { kesulitan karena saya bisa mengandalkan } \\
\text { kemampuan mengatasi saya }\left(\mathrm{X}_{1.7}\right)\end{array}$ & 0 & 2 & 22 & 52 & 21 & 3,95 & Tinggi \\
\hline $\begin{array}{l}\text { Ketika saya menghadapi masalah, saya dapat } \\
\text { menemukan beberapa solusi }\left(\mathrm{X}_{1.8}\right)\end{array}$ & 0 & 3 & 27 & 30 & 37 & 4,04 & Tinggi \\
\hline $\begin{array}{l}\text { Jika saya dalam masalah, saya bisa } \\
\text { memikirkan solusi yang bagus }\left(\mathrm{X}_{1.9}\right)\end{array}$ & 0 & 3 & 26 & 48 & 20 & 3,88 & Tinggi \\
\hline $\begin{array}{l}\text { Saya bisa menangani apapun yang datang } \\
\text { dengan cara saya }\left(\mathrm{X}_{1.10}\right)\end{array}$ & 0 & 5 & 17 & 46 & 29 & 4,02 & Tinggi \\
\hline \multicolumn{6}{|c|}{$\begin{array}{l}\left(X_{1.10}\right) \\
\text { Rata-rata Skor Variabel Efikasi Diri }\end{array}$} & 3,98 & Tinggi \\
\hline
\end{tabular}

Sumber: Data primer diolah, 2018

Dari kelima pernyataan tersebut, yang memiliki nilai paling tinggi adalah pernyataan "Saya selalu bisa mengatasi masalah sulit jika saya berusaha cukup keras". Hal tersebut disebabkan karena karyawan PT. Sukanda Djaya Cabang Denpasar sudah berusaha cukup keras dalam mengatasi setiap masalah pekerjaannya dengan baik. Skor rata-rata terendah pada variabel efikasi diri terdapat pada pernyataan, "Jika saya dalam masalah, saya bisa memikirkan solusi yang bagus" dengan nilai rata-rata sebesar 3,88. Hal tersebut menunjukkan bahwa masih ada beberapa orang karyawan PT. Sukanda Djaya Cabang Denpasar yang tidak dapat menemukan solusi yang bagus apabila sedang menghadapi masalah dalam pekerjaannya serta tidak memiliki keyakinan untuk dapat menyelesaikan masalah tersebut.

Hasil analisis deksriptif sebagaimana disajikan pada Tabel 8. menunjukkan bahwa variabel motivasi kerja secara keseluruhan memperoleh nilai rata-rata sebesar 3,95, yang berarti bahwa sebagian besar karyawan PT. Sukanda Djaya Cabang Denpasar sudah memiliki motivasi kerja yang tinggi. Dari 6 pernyataan yang digunakan untuk mengukur motivasi kerja, maka terdapat 4 pernyataan yang nilainya berada di atas nilai rata-rata $(3,95)$ variabel motivasi kerja. Dari keempat pernyataan tersebut, yang memiliki nilai paling tinggi adalah pernyataan, "Apabila saya menemui masalah dalam bekerja, saya tidak segan untuk bertanya pada rekan 
kerja". Hal tersebut disebabkan karena sebagian besar responden tidak segan untuk bertanya pada rekan kerjanya apabila sedang menghadapi masalah dalam bekerja.

Tabel 8.

Deskripsi Penilaian Responden Terhadap Variabel Motivasi Kerja

\begin{tabular}{|c|c|c|c|c|c|c|c|}
\hline \multirow[t]{2}{*}{ Indikator } & \multicolumn{5}{|c|}{$\begin{array}{c}\text { Frekuensi Jawaban } \\
\text { Responden }\end{array}$} & \multirow{2}{*}{$\begin{array}{c}\text { Rata - } \\
\text { Rata }\end{array}$} & \multirow[t]{2}{*}{ Keterangan } \\
\hline & 1 & 2 & $\mathbf{3}$ & 4 & 5 & & \\
\hline $\begin{array}{l}\text { Saya selalu berusaha sekuat tenaga } \\
\text { dalam mengerjakan tugas }\left(\mathrm{X}_{2.1}\right)\end{array}$ & 0 & 2 & 23 & 45 & 27 & 4,00 & Tinggi \\
\hline $\begin{array}{l}\text { Saya selalu melaksanakan pekerjaan } \\
\text { dengan penuh perhitungan }\left(\mathrm{X}_{2.2}\right)\end{array}$ & 0 & 9 & 30 & 38 & 20 & 3,71 & Tinggi \\
\hline $\begin{array}{l}\text { Apabila saya menemui masalah dalam } \\
\text { bekerja, saya tidak segan untuk } \\
\text { bertanya pada atasan }\left(\mathrm{X}_{2.3}\right)\end{array}$ & 0 & 6 & 20 & 50 & 21 & 3,89 & Tinggi \\
\hline $\begin{array}{l}\text { Apabila saya menemui masalah dalam } \\
\text { bekerja, saya tidak segan untuk } \\
\text { bertanya pada rekan kerja }\left(\mathrm{X}_{2.4}\right)\end{array}$ & 0 & 0 & 11 & 63 & 23 & 4,12 & Tinggi \\
\hline $\begin{array}{l}\text { Saya selalu bersemangat dalam } \\
\text { mengerjakan tugas dengan hasil yang } \\
\text { baik agar saya menjadi karyawan yang } \\
\text { berprestasi }\left(\mathrm{X}_{2.5}\right)\end{array}$ & 0 & 0 & 11 & 63 & 23 & 3,98 & Tinggi \\
\hline $\begin{array}{l}\text { Saya bertanggung jawab atas } \\
\text { kenyamanan klien }\left(\mathrm{X}_{2.6}\right)\end{array}$ & 0 & 2 & 16 & 61 & 18 & 4,01 & Tinggi \\
\hline \multicolumn{6}{|c|}{ Rata-rata Skor Variabel Motivasi Kerja } & 3,95 & Tinggi \\
\hline
\end{tabular}

Skor rata-rata terendah pada variabel motivasi kerja terdapat pada pernyataan, "Saya selalu melaksanakan pekerjaan dengan penuh perhitungan" dengan nilai rata-rata sebesar 3,71. Hal tersebut menunjukkan bahwa masih ada beberapa orang karyawan yang tidak mampu menyelesaikan tugas dengan penuh perhitungan dan tanggung jawab sesuai dengan prosedur yang telah ditentukan.

Hasil analisis deksriptif sebagaimana disajikan pada Tabel 9. menunjukkan bahwa variabel lingkungan kerja secara keseluruhan memperoleh nilai rata-rata sebesar 3,91, yang berarti bahwa sebagian besar karyawan menilai PT. Sukanda Djaya Cabang Denpasar sudah memiliki lingkungan kerja yang baik. Dari 6 pernyataan yang digunakan untuk mengukur lingkungan kerja, maka terdapat 4 pernyataan yang nilainya berada di atas nilai rata-rata $(3,91)$ variabel lingkungan kerja. Dari keempat pernyataan tersebut, yang memiliki nilai paling tinggi adalah pernyataan, "Hubungan saya dengan sesama karyawan terjalin dengan baik". Hal tersebut disebabkan karena secara keseluruhan karyawan PT. Sukanda Djaya Cabang Denpasar sudah menjalin hubungan yang baik dengan rekan kerjanya. Skor rata-rata terendah pada variabel lingkungan kerja terdapat pada pernyataan, "Fasilitas yang disediakan oleh perusahaan sudah memadai untuk melaksanakan pekerjaan", dengan nilai rata-rata sebesar 3,79. Pernyataan tersebut sudah memperoleh penilaian yang baik dari karyawan berdasarkan hasil kuesioner, namun masih lebih rendah dari nilai rata-rata variabel lingkungan kerja. Hal tersebut menunjukkan bahwa masih ada beberapa orang karyawan yang merasa 
bahwa fasilitas yang disediakan oleh perusahaan kurang memadai untuk melaksanakan pekerjaan.

Tabel 9.

Deskripsi Penilaian Responden Pada Variabel Lingkungan Kerja

\begin{tabular}{|c|c|c|c|c|c|c|c|}
\hline \multirow[t]{2}{*}{ Indikator } & \multicolumn{5}{|c|}{$\begin{array}{l}\text { Frekuensi Jawaban } \\
\text { Responden }\end{array}$} & \multirow{2}{*}{$\begin{array}{l}\text { Rata - } \\
\text { Rata }\end{array}$} & \multirow[t]{2}{*}{ Keterangan } \\
\hline & 1 & 2 & 3 & 4 & 5 & & \\
\hline $\begin{array}{l}\text { Penerangan lampu dalam ruangan } \\
\text { kerja saya sudah memadai }\left(\mathrm{X}_{3.1}\right)\end{array}$ & 0 & 1 & 17 & 67 & 12 & 3,93 & Baik \\
\hline $\begin{array}{l}\text { Kebersihan di perusahaan membuat } \\
\text { saya nyaman dalam bekerja }\left(\mathrm{X}_{3.2}\right)\end{array}$ & 0 & 1 & 21 & 55 & 20 & 3,97 & Baik \\
\hline $\begin{array}{l}\text { Fasilitas yang disediakan oleh } \\
\text { perusahaan sudah memadai untuk } \\
\text { melaksanakan pekerjaan }\left(\mathrm{X}_{3.3}\right)\end{array}$ & 0 & 3 & 27 & 54 & 13 & 3,79 & Baik \\
\hline $\begin{array}{l}\text { Perusahaan tempat saya bekerja } \\
\text { memberikan keamanan lingkungan } \\
\text { yang memadai }\left(\mathrm{X}_{3.4}\right)\end{array}$ & 0 & 2 & 23 & 49 & 23 & 3,96 & Baik \\
\hline $\begin{array}{l}\text { Hubungan saya dengan pimpinan } \\
\text { terjalin dengan baik }\left(\mathrm{X}_{3.5}\right)\end{array}$ & 0 & 8 & 23 & 42 & 24 & 3,85 & Baik \\
\hline $\begin{array}{l}\text { Hubungan saya dengan sesama } \\
\text { karyawan terjalin dengan baik }\left(\mathrm{X}_{3.6}\right)\end{array}$ & 0 & 2 & 19 & 53 & 23 & 4,00 & Baik \\
\hline \multicolumn{6}{|c|}{ Rata-rata Skor Variabel Lingkungan Keria } & 3,91 & Baik \\
\hline
\end{tabular}

Sumber: Data primer diolah, 2018

Model regresi akan lebih tepat digunakan dan menghasilkan perhitungan yang lebih akurat, apabila beberapa asumsi berikut dapat terpenuhi. Uji asumsi klasik yang harus dipenuhi pada analisis regresi linear sederhana antara lain Uji Normalitas, Uji Multikolenearitas dan Uji Heterokedastisitas.

Uji normalitas ini bertujuan untuk mengetahui apakah residual dari model regresi yang dibuat berdistribusi normal atau tidak. Dalam penelitian ini uji normalitas dilakukan dengan menguji normalitas residual dengan menggunakan uji Kolmogorov-Smirnov. Jika probabilitas signifikansi nilai residual lebih besar dari 0,05 maka data tersebut dikatakan berdistribusi normal. Demikian pula sebaliknya, jika probabilitas signifikansi residual lebih rendah dari 0,05 maka data tersebut dikatakan tidak berdistribusi normal.

Berdasarkan hasil analisis pada tabel 10 didapat nilai signifikansi sebesar 0,809 seperti yang ditunjukkan oleh Tabel 10. Oleh karena nilai signifikansi uji Kolmogorov-Smirnov lebih dari 0,05 maka dapat disimpulkan bahwa model persamaan regresi tersebut berdistribusi normal.

Tabel 10.

Hasil Uji Normalitas

\begin{tabular}{cc}
\hline & Unstandardized Residual \\
\hline $\mathrm{N}$ & 97 \\
Kolmogorov-Smirnov Z & 0,639 \\
Asymp.Sig.(2-tailed) & 0,809 \\
\hline
\end{tabular}

Sumber: Data primer diolah, 2018 
Uji multikolinearitas bertujuan untuk menguji apakah dalam satu model regresi ditemukan adanya korelasi antar variabel bebas. Model regresi yang baik adalah tidak terjadi korelasi diantara variabel bebas. Untuk mendeteksi ada atau tidaknya korelasi antar variabel bebas dapat dilihat dari nilai tolerance dan nilai variance inflation factor (VIF). Jika nilai tolerance lebih dari $10 \%$ atau VIF Kurang dari 10, maka dapat dikatakan model telah bebas dari multikolinearitas.

Berdasarkan Tabel 11 dapat dilihat bahwa nilai tolerance dan VIF dari seluruh variable tersebut menunjukkan bahwa nilai tolerance untuk setiap variabel lebih besar dari $10 \%$ dan nilai VIF lebih kecil dari 10 yang berarti model persamaan regresi bebas dari multikolinearitas.

Tabel 11.

Hasil Uji Multikoleniaritas

\begin{tabular}{cccc}
\hline Variabel & Tolerance & VIF & Keterangan \\
\hline Efikasi Diri $\left(\mathrm{X}_{1}\right)$ & 0,424 & 2,361 & Bebas multikol \\
Motivasi Kerja $\left(\mathrm{X}_{2}\right)$ & 0,546 & 1,831 & Bebas multikol \\
Lingkungan Kerja $\left(\mathrm{X}_{3}\right)$ & 0,630 & 1,587 & Bebas multikol \\
\hline
\end{tabular}

Sumber: Data primer diolah, 2018

Uji heteroskedastisitas ini bertujuan untuk mengetahui apakah dalam model regresi terjadi ketidaksamaan varians dari residual satu pengamatan ke pengamatan lain yang dilakukan dengan uji Glejser. Model regresi yang baik adalah yang tidak mengandung gejala heteroskedastisitas atau mempunyai varians yang homogen. Jika variabel bebas yang diteliti tidak mempunyai pengaruh signifikan atau nilai signifikansinya lebih dari 0,05 terhadap nilai absolute residual, berarti model regresi tidak mengandung gejala heteroskedastisitas. Hasil pengujian heteroskedastisitas disajikan pada Tabel 12. berikut.

Pada Tabel 12. dapat dilihat bahwa nilai Signifikansi dari variabel Efikasi Diri sebesar 0,557, Motivasi Kerja sebesar 0,572, dan Lingkungan Kerja sebesar 0,624 . Nilai tersebut lebih besar dari 0,05 yang berarti tidak terdapat pengaruh antara variabel bebas terhadap absolute residual. Dengan demikian, model yang dibuat tidak mengandung gejala heteroskedastisitas.

Tabel 12.

Hasil Uji Heteroskedastisitas

\begin{tabular}{clcl}
\hline No & \multicolumn{1}{c}{ Variabel Bebas } & Signifikansi & Keterangan \\
\hline 1 & Efikasi Diri & 0,557 & Bebas heteros \\
2 & Motivasi Kerja & 0,572 & Bebas heteros \\
3 & Lingkungan Kerja & 0,624 & Bebas heteros \\
\hline
\end{tabular}

Sumber: Data primer diolah, 2018

Berdasarkan uraian pada Tabel 10. Tabel 11. dan Tabel 12, menunjukkan bahwa semua uji asumsi klasik sudah terpenuhi sehingga hasil analisis regresi layak untuk dibahas lebih lanjut. 
Pengujian data dalam penelitian ini menggunakan teknik regresi linier berganda. Perhitungan koefisien dilakukan dengan analisis regresi melalui software SPSS 18.0 for Windows, diperoleh hasil yang ditunjukan pada Tabel 13 .

Tabel 13.

Hasil Analisis Regresi Linier Berganda

\begin{tabular}{|c|c|c|c|c|c|}
\hline \multirow[t]{2}{*}{ Variabel } & \multicolumn{2}{|c|}{$\begin{array}{c}\text { Unstandardized } \\
\text { Coefficients }\end{array}$} & \multirow{2}{*}{$\begin{array}{c}\text { Standardized } \\
\text { Coefficients } \\
\text { Beta }\end{array}$} & \multirow[t]{2}{*}{$\mathbf{t}$} & \multirow[t]{2}{*}{ Sig. } \\
\hline & B & Std. error & & & \\
\hline (constant) & -6.705 & 1.617 & & -4.145 & .000 \\
\hline Efikasi diri & .109 & .052 & .191 & 2.098 & .039 \\
\hline Motivasi kerja & .480 & .075 & .515 & 6.408 & .000 \\
\hline Lingkungan kerja & .254 & .074 & .256 & 3.426 & .001 \\
\hline$R$ Square & & & & & 0,673 \\
\hline Adjusted R Square & & & & & 0,662 \\
\hline F Statistik & & & & & 63,685 \\
\hline Signifikansi Uji F & & & & & 0,000 \\
\hline
\end{tabular}

Berdasarkan hasil analisis regresi linier berganda seperti yang disajikan pada Tabel 13, maka dapat dibuat persamaan regresi sebagai berikut: $\mathrm{Y}=-6,705+0,191 \mathrm{X}_{1}+0,515 \mathrm{X}_{2}+0,256 \mathrm{X}_{3}$

Nilai koefisien regresi masing-masing variabel bebas bernilai positif dengan nilai signifikansi uji t kurang dari 0,05 . Hal ini menunjukkan bahwa semua variabel bebas memiliki pengaruh positif yang signifikan terhadap variabel terikat. Besarnya pengaruh variabel bebas terhadap variabel terikat yang ditunjukkan oleh nilai determinasi total (R Square) sebesar 0,662 mempunyai arti bahwa sebesar 66,2\% variasi kepuasan kerja karyawan PT. Sukanda Djaya Cabang Denpasar dipengaruhi oleh variasi Efikasi Diri, Motivasi Kerja, dan Lingkungan Kerja, sedangkan sisanya sebesar $33,8 \%$ djelaskan oleh faktor lain yang tidak dimasukkan ke dalam model.

Uji ketepatan model regresi bertujuan untuk mengetahui apakah semua variabel bebas yang diidentifikasi (Efikasi Diri, Motivasi Kerja, dan Lingkungan Kerja) tepat digunakan memprediksi kepuasan kerja karyawan. Uji ini sering juga disebut dengan uji F. Hasil uji F (Ftest) pada Tabel 10. menunjukkan bahwa nilai signifikansi P value 0,000 yang lebih kecil dari $\alpha=0,05$, ini berarti model yang digunakan pada penelitian ini adalah layak. Hasil ini memberikan makna bahwa seluruh variabel independen mampu memprediksi atau menjelaskan fenomena kepuasan kerja karyawan PT. Sukanda Djaya Cabang Denpasar. Hal ini berarti model dapat digunakan untuk analisa lebih lanjut atau dengan kata lain model dapat digunakan untuk memproyeksikan karena hasil goodness of fitnya baik dengan nilai signifikansi $\mathrm{P}$ value 0,000 .

Pengaruh variabel Efikasi Diri, Motivasi Kerja, dan Lingkungan Kerja, terhadap kepuasan kerja karyawan yang diuji dengan menggunakan Uji t. Kriteria pengujian untuk menjelaskan interpretasi pengaruh antar masing-masing variabel yakni apabila nilai signifikansi $<0,05$ maka $\mathrm{H}_{0}$ ditolak dan $\mathrm{H}_{1}$ diterima. Sebaliknya, jika nilai signifikansi $>0,05$ maka $\mathrm{H}_{0}$ diterima dan $\mathrm{H}_{1}$ ditolak. 
Efikasi diri merupakan tingkat keyakinan atau kepercayaan seseorang terhadap kekuatan diri (percaya diri) dalam mengerjakan dan menjalankan suatu tugas atau pekerjaan tertentu. Efikasi diri adalah keyakinan seseorang mengenai peluangnya untuk berhasil mencapai tugas tertentu (Kreitner dan Kinicki, 2005:79). Beberapa penelitian akademik telah membuktikan bahwa efikasi diri berhubungan dengan kontrol diri, ketahanan dalam menghadapi kegagalan, kinerja dan upaya dalam pemecahan masalah (Cherian \& Jacob, 2013).

Hasil analisis pengaruh efikasi diri terhadap kepuasan kerja pada Tabel 13 menujukkan nilai Signifikasi sebesar 0,039 dengan nilai koefisien beta 0,191. Nilai Signifikansi 0,039 $<0,05$ mengindikasikan bahwa $\mathrm{H}_{0}$ ditolak dan $\mathrm{H}_{1}$ diterima. Hasil ini mempunyai arti bahwa Efikasi diri berpengaruh positif dan signifikan terhadap kepuasan kerja karyawan PT. Sukanda Djaya Cabang Denpasar. Semakin tinggi tingkat kepercayaan karyawan saat bekerja di PT. Sukanda Djaya Cabang Denpasar maka akan semakin tinggi pula kepuasan kerja yang dirasakan karyawan tersebut. Begitu pula sebaliknya, semakin rendah tingkat kepercayaan diri karyawan PT. Sukanda Djaya Cabang Denpasar, maka akan semakin mengurangi kepuasan kerja yang dirasakan karyawan.

Penelitian ini mendukung beberapa hasil penelitian sebelumnya dan konsisten dengan hasil penelitian yang dilakukan oleh (Lau, 2012) yang menunjukkan hasil bahwa efikasi diri berhubungan positif dengan kepuasan kerja. Semakin tinggi efikasi diri seseorang semakin tinggi pula kepuasan kerja seseorang. Hal ini membuktikan bahwa efikasi diri yang dimiliki oleh seorang karyawan memberikan dorongan terhadap kepuasan kerja. Karena mereka menganggap bahwa pada dasarnya setiap orang pasti memiliki efikasi diri, tetapi efikasi diri tersebut terbentuk karena dukungan dari organisasi. Hasil penelitian ini juga sejalan dengan penelitian yang dilakukan oleh (Lodjo, 2013) yang memperoleh hasil bahwa Efikasi Diri berpengaruh positif dan signifikan terhadap kepuasan kerja karyawan. Oleh karena itu keyakinan diri sangatlah penting. Semakin mampu dan yakin seseorang dalam mengerjakan tugasnya akan semakin tinggi kepuasan kerja karyawan tersebut.

Motivasi merupakan suatu rangsangan yang dibuat oleh organisasi guna meningkatkan gairah bekerja pada karyawan. Motivasi adalah kekuatan yang dihasilkan dari keinginan seseorang untuk memuaskan dan memenuhi kebutuhannya (Purwanto, 2013). Motivasi mendorong seseorang untuk melakukan tindakan yang membantu mereka untuk mencapai efektivitas tugas dengan cara yang dapat menginspirasi orang untuk pekerjaan mereka dan dapat membawa lebih banyak motivasi kerja terhadap komitmen dan keyakinan diri mereka terhadap pekerjaan atau tugas tertentu.

Hasil analisis pengaruh motivasi kerja terhadap kepuasan kerja pada Tabel 13 menunjukkan nilai signifikansi sebesar 0,000 dengan nilai koefisien beta 0,515. Nilai Signifikansi $0,000<0,05$ mengindikasikan bahwa $\mathrm{H}_{0}$ ditolak dan $\mathrm{H}_{2}$ diterima. Hasil ini mempunyai arti bahwa motivasi kerja berpengaruh positif dan signifikan terhadap kepuasan kerja karyawan PT. Sukanda Djaya Cabang Denpasar. Semakin tinggi motivasi kerja yang dimiliki karyawan PT. Sukanda Djaya Cabang Denpasar maka kepuasan kerja karyawan tersebut juga akan semakin bertambah. Begitu pula sebaliknya, semakin rendah motivasi kerja 
karyawan PT. Sukanda Djaya Cabang Denpasar, maka semakin rendah tingkat kepuasan kerja karyawan tersebut.

Penelitian ini mendukung beberapa hasil penelitian sebelumnya dan konsisten dengan hasil penelitian (Kartika \& Kaihatu, 2010) yang memperoleh hasil bahwa motivasi kerja berpengaruh signifikan terhadap kepuasan kerja. Bila karyawan memiliki motivasi kerja yang tinggi, diharapkan akan termotivasi untuk menyelesaikan tugas dengan cepat dan tepat sehingga timbul kepuasan kerja. Penelitian ini juga di dukung oleh hasil penelitian (Brahmasari \& Suprayetno, 2008), serta (Djamaludin, 2009) yang memperoleh hasil bahwa motivasi kerja berpengaruh positif pada kepuasan kerja, yaitu semakin tinggi motivasi kerja maka semakin tinggi kepuasan kerja karyawan. Hal ini membuktikan bahwa motivasi diri yang dimiliki oleh seorang karyawan memberikan dorongan terhadap kepuasan kerja. Oleh karena itu motivasi diri sangatlah penting. Semakin tinggi motivasi seseorang dalam mengerjakan tugasnya akan semakin tinggi kepuasan kerja karyawan tersebut.

Lingkungan kerja adalah lingkungan dimana karyawan melakukan pekerjaannya sehari-hari. Lingkungan kerja yang kondusif memberikan rasa aman dan memungkinkan para karyawan untuk dapat berkerja optimal. Lingkungan kerja dapat mempengaruhi emosi karyawan. Jika karyawan menyenangi lingkungan kerja dimana dia bekerja, maka karyawan tersebut akan betah di tempat kerjanya untuk melakukan aktivitas sehingga waktu kerja dipergunakan secara efektif dan optimis prestasi kerja karyawan juga tinggi. Lingkungan kerja tersebut mencakup hubungan kerja yang terbentuk antara sesama karyawan dan hubungan kerja antar bawahan dan atasan serta lingkungan fisik tempat karyawan bekerja (Mardiana, 2005)

Hasil analisis pengaruh lingkungan kerja terhadap kepuasan kerja pada Tabel 13 menunjukkan nilai signifikansi sebesar 0,001 dengan nilai koefisien beta 0,256. Nilai signifikansi 0,001 $<0,05$ mengindikasikan bahwa $\mathrm{H}_{0}$ ditolak dan $\mathrm{H}_{3}$ diterima. Hasil ini mempunyai arti bahwa lingkungan kerja berpengaruh positif dan signifikan terhadap kepuasan kerja karyawan PT. Sukanda Djaya Cabang Denpasar. Semakin baik kondisi lingkungan kerja maka akan berpengaruh pada semakin meningkatnya kepuasan kerja karyawan PT. Sukanda Djaya Cabang Denpasar. Begitu pula sebaliknya, semakin buruk kondisi Lingkungan Kerja pada PT. Sukanda Djaya Cabang Denpasar maka akan berpengaruh pada semakin berkurangnya kepuasan kerja karyawan.

Penelitian ini mendukung beberapa hasil penelitian sebelumnya dan konsisten dengan hasil penelitian yang dilakukan oleh (Medina et al., 2013) yang menunjukkan bahwa ada hubungan yang positif antara lingkungan kerja dan kepuasan kerja. Hasil penelitian ini juga di dukung oleh (Kurniasari \& Halim, 2013), (Bahri et al., 2013), dan (baraba, 2014) yang memperoleh hasil bahwa ada pengaruh yang positif dan signifikan antara lingkungan kerja terhadap kepuasan kerja karyawan. Hal ini membuktikan bahwa lingkungan kerja yang baik dan mendukung pada suatu perusahaan akan mampu memberikan dorongan terhadap kepuasan kerja karyawannya. Oleh karena itu lingkungan kerja sangatlah penting. Semakin baik lingkungan kerja seseorang dalam mengerjakan tugasnya akan semakin tinggi kepuasan kerja karyawan tersebut. 
Berdasarkan hasil penelitian yang diperoleh terdapat beberapa implikasi strategis yaitu pertama, secara umum tingkat keyakinan atau kepercayaan seseorang karyawan dapat mempengaruhi kepuasan kerja. Pernyataan dengan nilai tertinggi yaitu "Saya selalu bisa mengatasi masalah sulit jika saya berusaha cukup keras". Pernyataan tersebut menunjukkan bahwa karyawan PT. Sukanda Djaya Cabang Denpasar sudah berusaha cukup keras dalam mengatasi setiap masalah pekerjaannya dengan baik.

Kedua, diketahui bahwa motivasi kerja yang tinggi dapat menambah tingkat kepuasan kerja karyawan, hal ini dapat dilihat dari pernyataan dengan nilai tertinggi yaitu "Apabila saya menemui masalah dalam bekerja, saya tidak segan untuk bertanya pada rekan kerja". Hal tersebut menandakkan bahwa sebagian besar responden tidak segan untuk bertanya pada rekan kerjanya apabila sedang menghadapi masalah dalam bekerja.

Ketiga, diketahui bahwa lingkungan kerja yang baik dan kondusif dapat menambah tingkat kepuasan kerja karyawan, hal ini dapat dilihat dari pernyataan dengan nilai tertinggi yaitu "Hubungan saya dengan sesama karyawan terjalin dengan baik". Hal tersebut menandakkan bahwa secara keseluruhan karyawan PT. Sukanda Djaya Cabang Denpasar sudah menjalin hubungan yang baik dengan rekan kerjanya, sehingga mampu membetuk lingkungan kerja yang kondusif.

Implikasi keempat yaitu, variabel yang terdapat dalam penelitian ini seperti efikasi diri, motivasi kerja dan lingkungan kerja, dimana hasil yang diperoleh setiap variabel positif dan signifikan, hal tersebut membuktikan bahwa karyawan sudah memiliki kepuasan kerja yang cukup tinggi, hal ini merupakan langkah selanjutnya bagi PT. Sukanda Djaya Cabang Denpasar untuk dapat mempertahankan bahkan meningkatkan kepuasan kerja karyawan agar tujuan perusahaan dapat tercapai, baik dengan cara mempertahankan hubungan yang harmonis antar karyawan, maupun mempertahankan sikap saling tolong menolong di antara karyawan yang sedang mengalami kesulitan dalam menyelesaikan pekerjaannya.

Berdasarkan penelitian yang telah dilakukan, terdapat keterbatasan dalam penelitian ini yaitu pertama ruang lingkup penelitian hanya mencakup kepuasan kerja karyawan PT. Sukanda Djaya Cabang Denpasar Sehingga tidak dapat menggambarkan kepuasan kerja karyawan PT. Sukanda Djaya secara umum di Indonesia. Kedua, faktor yang mempengaruhi kepuasan kerja karyawan dalam penelitian ini adalah efikasi diri, motivasi kerja dan lingkungan kerja, sedangkan masih banyak faktor lain yang mempengaruhi kepuasan kerja karyawan seperti kompensasi, kondisi kerja, mutu pengawasan, teman sekerja, jenis pekerjaan, keamanan kerja, kesempatan untuk maju dan faktor individu seperti umur, pangkat, ataupun kedudukan karyawan tersebut. Ketiga, penelitian ini hanya dilakukan dalam titik waktu tertentu, sedangkan lingkungan setiap saat berubah, sehingga penelitian ini penting untuk dilakukan kembali dimasa mendatang.

\section{SIMPULAN}

Berdasarkan hasil analisis penelitian dan hasil pembahasan maka simpulan dari penelitian ini yaitu efikasi diri berpengaruh positif dan signifikan terhadap kepuasan kerja, motivasi kerja berpengaruh positif dan signifikan terhadap 
kepuasan kerja, serta lingkungan kerja berpengaruh positif dan signifikan terhadap kepuasan kerja.

Saran yang dapat diberikan berdasarkan hasil penelitian yaitu dalam upaya meningkatkan efikasi diri karyawan menjadi lebih tinggi, maka PT. Sukanda Djaya Cabang Denpasar sebaiknya membuat pelatihan dan pendidikan karyawan dengan memberi materi dan pemahaman terkait masalah-masalah yang akan dihadapi saat bekerja dan solusi dalam memecahkan setiap masalah kepada seluruh karyawan, sehingga diharapkan dapat meningkatkan efikasi diri dan kinerja karyawan menjadi lebih baik.

Kemudian untuk meningkatkan motivasi kerja karyawan, maka PT. Sukanda Djaya Cabang Denpasar sebaiknya membuat program pengembangan bagi seluruh karyawan agar seluruh karyawan mampu membuat perhitungan dalam menyelesaikan pekerjaan dengan baik dan tepat waktu. Lalu, dalam upaya meningkatkan lingkungan kerja menjadi lebih baik, maka PT. Sukanda Djaya Cabang Denpasar sebaiknya meningkatkan fasilitas kerja yang dinilai kurang memadai bagi karyawan, dengan fasilitas kerja yang lengkap diharapkan dapat meningkatkan lingkungan kerja dan kinerja karyawan menjadi lebih baik. Selanjutnya, untuk meningkatkan kepuasan kerja karyawan menjadi lebih baik, maka PT. Sukanda Djaya Cabang Denpasar sebaiknya bersedia memberikan kesempatan promosi jabatan kepada seluruh karyawan yang memiliki prestasi yang tinggi melalui kompetisi yang adil, sehingga nantinya dapat meningkatkan kepuasan kerja karyawan dan pada akhirnya kinerja karyawan menjadi lebih baik. Hasil dari penelitian ini diharapkan mampu mendorong peneliti-peneliti selanjutnya untuk mengamati faktor-faktor lain yang dapat mempengaruhi kepuasan kerja selain efikasi diri, motivasi kerja, dan lingkungan kerja. Penelitian selanjutnya juga diharapkan dapat menambah jumlah sampel penelitian serta memperluas wilayah sampel penelitian, sehingga nanti hasilnya dapat digeneralisasikan untuk lingkup yang lebih luas.

\section{REFERENSI}

Ahmed, I. (2014). Effects of Motivational factors on Employees Job Satisfaction: A case study of University of the Punjab, Pakistan. International Journal of Business and Management, 5(3). https://doi.org/10.5539/ijbm.v5n3p70

Arasl1, H., Daşkın, M., \& Saydam, S. (2014). Polychronicity and Intrinsic Motivation as Dispositional Determinants on Hotel Frontline Employees' Job Satisfaction: Do Control Variables Make a Difference? Procedia - Social and Behavioral Sciences, 109, 1395-1405. https://doi.org/10.1016/j.sbspro.2013.12.643

Bahri, M. R. Z., Langrudi, M. S., \& Hosseinian, S. (2013). Relationship of work environment variables and job satisfaction of employees with counterproductive work behaviors: A study of non-governmental non-benefit Islamic Azad University employees in West Mazandaran. World Applied Sciences Journal, 21(12), 1812-1815. https://doi.org/10.5829/idosi.wasj.2013.21.12.1565 
baraba, ridwan. (2014). Pengaruh komitmen organisasi dan lingkungan kerja terhadap kepuasan kerja karyawan universitas muhammadiyah purworejo dengan keyakinan diri sebagai variabel pemoderasi. 10(1).

Betz, N. E. (2004). Contributions of self-efficacy theory to career counseling: A personal perspective. Career Development Quarterly, 52(4), 340-353. https://doi.org/10.1002/j.2161-0045.2004.tb00950.x

Brahmasari, I. ., \& Suprayetno, A. (2008). Pengaruh Motivasi Kerja, Kepemimpinan dan Budaya Organisasi Terhadap Kepuasan Kerja Karyawan serta Dampaknya pada Kinerja Perusahaan (Studi kasus pada PT. Pei Hai International Wiratama Indonesia). (1996), 124-135. Retrieved from http://jurnalmanajemen.petra.ac.id/index.php/man/article/view/17039

Çekmecelioğlu, H. G., Günsel, A., \& Ulutaş, T. (2012). Effects of Emotional Intelligence on Job Satisfaction: An Empirical Study on Call Center Employees. Procedia - Social and Behavioral Sciences, 58, 363-369. https://doi.org/10.1016/j.sbspro.2012.09.1012

Chatzopoulou, M., Vlachvei, A., \& Monovasilis, T. (2015). Employee's Motivation and Satisfaction in Light of Economic Recession: Evidence of Grevena Prefecture-Greece. Procedia Economics and Finance, 24(July), 136-145. https://doi.org/10.1016/s2212-5671(15)00633-4

Cherian, J., \& Jacob, J. (2013). Impact of Self Efficacy on Motivation and Performance of Employees. International Journal of Business and Management, 8(14), 80-88. https://doi.org/10.5539/ijbm.v8n14p80

Djamaludin, M. (2009). Pengaruh Komitmen Organisasional, Pengembangan Karier, Motivasi Kerja Dan Karakteristik Individual Terhadap Kepuasan Kerja Dan Kinerja Pegawai Pemerintah Kabupaten Halmahera Timur. 5.

Gardjito, A. H., Musadieq, M. Al, \& Nurtjahjono, G. E. (2011). Pengantar Ilmu Komunikasi Dan Peran Manajemen Dalam Komunikasi. Jurnal Administrasi Bisnis (JAB), 13(1), 1-8. Retrieved from http://administrasibisnis.studentjournal.ub.ac.id/index.php/jab/article/view/53 1

Horwitz, F. M., Heng, C. T., \& Quazi, H. A. (2003). and Retaining Knowledge Workers. Human Resource Management, 13(4), 23-44. https://doi.org/10.1111/j.1748-8583.2003.tb00103.x

Jain, R., \& Kaur, S. (2014). Impact of Work Environment On Job. International Journal of Scientific and Research Publications, 4(1), 1-8. 
Karabiyik, B., \& Korumaz, M. (2014). Relationship between Teacher's Selfefficacy Perceptions and Job Satisfaction Level. Procedia - Social and Behavioral Sciences, 116, 826-830. https://doi.org/10.1016/j.sbspro.2014.01.305

Kartika, E. W., \& Kaihatu, T. S. (2010). Analisis Pengaruh Motivasi Kerja Terhadap Kepuasan Kerja (Studi Kasus pada Karyawan Restoran di Pakuwon Food Festival Surabaya). Jurnal Manajemen Dan Kewirausahaan (Journal of Management and Entrepreneurship), 12(1), 100-112. https://doi.org/10.9744/jmk.12.1.pp. 100-112

Koesmono, T. (2005). Pengaruh Budaya Organisasi Terhadap Motivasi Dan Kepuasan Kerja Serta Kinerja Karyawan Pada Sub Sektor Industri Pengolahan Kayu Skala Menengah Di Jawa Timur. IEEE Software. https://doi.org/10.1109/MS.2008.35

Kurniasari, D., \& Halim, A. (2013). Pengaruh Lingkungan Kerja Dan Iklim Organisasi Terhadap Komitmen Organisasi Melalui Kepuasan Kerja Karyawan Pada Dinas Pasar Unit Pasar Tanjung Kabupaten Jember. Jurnal Ilmu Ekonomi, 8(2), 273.

Lau, W. K. (2012). The impacts of personality traits and goal commitment on employees' job satisfaction. Business and Economics Journal, 2012(BEJ59), $1-12$.

Lodjo, F. S. (2013). Pengaruh Pelatihan, Pemberdayaan dan Efikasi Diri Terhadap Kepuasan Kerja. Pengaruh Pelatihan, Pemberdayaan Dan Efikasi Diri Terhadap Kepuasan Kerja, 1(3), 747-755.

Mardiana. (2005). Manajemen Produksi. Jakarta: Badan Penerbit IPWI.

Medina, J., Garza, I. D. la, \& Cheín, N. (2013). The Impact of Stress and the Working Environment on Job Satisfaction and Decision- Making among Women Entrepreneurs in Mexico. International Journal of Business and Social Research, 3(3), 164-173.

Mishra, U. S., Patnaik, S., \& Mishra, B. B. (2016). Augmenting Human Potential At Work: an Investigation on the Role of Self-Efficacy in Workforce Commitment and Job Satisfaction. Polish Journal of Management Studies, 13(1), 134-144. https://doi.org/10.17512/pjms.2016.13.1.13

Pahi, M. H., Shah, S. M. M., Ahmed, U., \& Umrani, W. A. (2017). Investigating the Issue of Nurse Job Satisfaction: Role of Esprit De Corps, Task Significance, Self-Efficacy and Resilience: A Case Study. International Journal of Academic Research in Business and Social Sciences, 6(4). https://doi.org/10.6007/ijarbss/v6-i4/2112 
Purwanto, S. B. (2013). Pengaruh Komunikasi , Motivasi dan Kepuasan Kerja terhadap Kinerja Karyawan ( Studi pada Proyek Pondasi Tower di Timor Leste PT Cahaya Inspirasi Indonesia ). Aplikasi Manajemen, 11(66), 139144.

Robbins, S. P., \& Judge, T. A. (2015). Perilaku Organisasi (16th ed.). Jakarta: Salemba Empat.

Rohmawati, E. (2014). Analisis Pengaruh Iklim Etika Organisasi dan Efikasi Diri Terhadap Keinginan Berpindah Kerja dengan Kepuasan Kerja sebagai Variabel Pemediasi. Universitas Gajah Mada.

Soeghandi, V. M., Sutanto, E. M., \& Setiawan, R. (2013). Pengaruh kepuasan kerja dan loyalitas kerja terhadap organizational citizenship behavior. Agora, 1(1), 808-819.

Syahyuti. (2010). Defenisi, Variabel, Indikator dan Pengukuran Dalam Ilmu Sosial. Jakarta.

Wae-esor, E., Bin, A., Bakar, A., \& Hee, H. C. (2016). the Relationship Between Work Motivation and Job Satisfaction of Muslim Public Health Employees in. 2(1), 162-171.

Waspodo, A. A., \& Minadaniati, L. (2012). Pengaruh Kepuasan Kerja dan Iklim Organisasi Terhadap Organizational Citizenship Behavior (OCB). Journal.Unj.Ac.Id, 3(1), 1-16. Retrieved from http://journal.unj.ac.id/unj/index.php/jrmsi/article/view/768 